\title{
Una interpretación alternativa de la crítica platónica a la poesía: las soluciones de Platón a la crisis poética del siglo $\mathrm{V}$
}

\author{
M. ${ }^{a}$ Elena Macua MarTíneZ \\ UPV/EHU. Dpto. Estudios Clásicos \\ mariaelena.macua@ehu.es
}

Recibido: 7-05-2013

Aceptado: 16-12-2013

\section{RESUMEN}

El artículo revisa las opiniones de Platón sobre la poesía a la luz de la profunda crisis que sufre a mediados del siglo $\mathrm{v}$ el modelo poético tradicional. Los poetas del momento oscilan entre la fidelidad a los presupuestos de tal modelo, arraigado en la trascendencia y en la sustancialidad del lenguaje, pero a costa de excluir como materia poética la experiencia humana en su incómoda complejidad; y la asunción de una noción técnica del lenguaje, que conduce al cultivo de una poesía pragmática, vinculada exclusivamente a lo privado. En este contexto hay que ubicar las reflexiones de Platón sobre la poesía, que pueden entenderse como una sucesión de intentos por encontrar una salida propia a esta crisis, que van desde la reivindicación del modelo entusiástico tradicional y la desvalorización de la poesía técnica, hasta la inquietante síntesis de las Leyes en la figura del legislador-poeta.

Palabras clave: Platón, Poética.

\begin{abstract}
This essay revises Plato's views on poetry in the light of the middle $5^{\text {th }}$ - century's deep crisis that the traditional poetic model was going through. Poets of that period either remain loyal to the traditional model based upon the transcendence and substance of language at the expense of excluding human experience and its uncomfortable complexity in their poems; or else they assume a technical view of language which leads to a more analytical and pragmatic poetry solely linked to the private realm. In this context we have to place Plato's views on poetry, which may then be understood as a series of personal attempts to find a solution to the crisis thus, he vindicates the traditional 'enthusiastic' model, and deprecates the technical poetry, and goes as far as to the worrying synthesis of the Laws in the figure of the legislator-poet.
\end{abstract}

Keywords: Plato, Poetics.

I. Uno de los temas de los diálogos platónicos que ha suscitado mayor interés y causado más perplejidad, ha sido el de la crítica que lanza contra la poesía un autor de tan incomparable talento literario. Esta censura se ha justificado a partir de la antítesis que el propio Platón fundamenta entre el discurso poético y el discurso filosófico, los cuales, según afirma Sócrates en la República, X, 607b-c, estuvieron en Grecia, desde 
antiguo (palaiá), en querella (diaforá) y oposición (enantióseos). Un estudio reciente que argumenta la falacia de tal litigio es el de Most (2011: pp. 3-12), quien demuestra que los testimonios que aporta Sócrates para justificar la «vieja» hostilidad de los poetas hacia los filósofos, son probablemente citas de la primera versión, hoy perdida, de Las Nubes de Aristófanes, un contemporáneo suyo. Es decir, Platón hace extensiva al pasado la perspectiva presente sobre ambos tipos de discurso (la misma desde la que invalida, por ejemplo, el sistema de valores homérico).

Sin embargo, no es, en rigor, novedosa la aproximación de Most a esta cuestión: hace ya más de cincuenta años que las investigaciones de estudiosos como Cassirer o Colli (que sigue, por otra parte, la estela abierta por Nietszche años atrás) pusieron en evidencia que el discurso poético y el filosófico evolucionan en Grecia paralelamente $\mathrm{y}$ de forma semejante desde sus orígenes.

Pese a todo, es posible que hayamos continuado planteando de forma parcial las opiniones de Platón sobre la poesía, porque, incluso teniendo conciencia de la conclusión precedente, hemos seguido interpretándolas aisladamente, es decir, sin ubicarlas en un contexto más amplio, en este caso, el de la historia de la teoría poética inmediatamente precedente, que fue elaborada indistintamente por poetas y filósofos. Por ello, en este trabajo nos proponemos revisar la cuestión platónica desde dicha perspectiva, tras hacer un análisis previo de la profunda crisis que, a mediados del siglo $\mathrm{v}$, experimenta en Atenas el modelo poético tradicional, heredero de la poesía arcaica, e insostenible tras la demoledora teoría gorgiana del Lógos.

Los poetas del momento oscilan entre dos extremos: por un lado, la fidelidad a los presupuestos básicos de tal modelo, arraigado en la trascendencia y en la sustancialidad del lenguaje, que adquiere la índole moral de aquello que describe y la inculca en el alma pasivamente «hechizada» del oyente; pero la prioridad que se concede ahora a esa necesidad de placentera evasión, tienta a excluir como materia poética lo netamente humano en su incómoda complejidad, y a desvincular la poesía de la experiencia vital, tornándola, así, socialmente inútil. Por otro lado, la asunción de la concepción técnica del lenguaje como medio de descripción moralmente neutro, y una priorización del imperativo de satisfacer las necesidades prácticas particulares del receptor, dan como resultado una poesía de lo inmediato y privado, racional y pragmática, pero sin poder para arrastrar a la colectividad hacia metas comunes más altas. Sin embargo, la conciencia de esta pérdida se manifiesta con extraordinaria claridad en poetas como Aristófanes y Eurípides, quienes plantean en sus obras la necesidad de lograr una síntesis entre ambos modelos poéticos para recuperar la eficacia política del arte precedente.

Esta es la crisis que hereda Platón, y en cuyo contexto proponemos plantear la evolución de su pensamiento en torno a la poesía como una sucesión de intentos por ofrecer soluciones propias a este conflicto, que cobra importancia creciente en sus obras a medida que se impone su vocación política.

II. La reflexión griega sobre la poesía se articula desde sus orígenes en torno a los tres elementos que intervienen en la comunicación poética: su naturaleza y origen (emisor), la configuración del mensaje (definición de forma y contenido, y del tipo de vínculo entre ambos), y su función social (efectos en el receptor). Y arranca, en rigor, de la problematización que genera, ya en Hesíodo, la incipiente conciencia de 
la intervención humana en la creación poética. Las «mentiras semejantes a verdades» que sus Musas (Th., 27) dicen a veces, ponen en duda la incuestionable coincidencia homérica $(\mathrm{Od}$. XI, 363-68) entre belleza y verdad que emana de una visión mítica de la dignidad y potencia de la palabra celestial ${ }^{1}$, y que permite transferir una verdad imparcial e impersonal al receptor, suscitando en él una instancia de pasiva fascinación (thélxis, el mismo término que utilizarán siglos después Gorgias y Platón para describir los efectos de la poesía), cuya «gestión» irá asumiendo el poeta en la medida en que crezca el grado de conciencia de su responsabilidad en el canto. En cualquier caso, Hesíodo consigue preservar el genuino vínculo poético entre placer y conocimiento, sobreponiéndose a los problemas que esas dudas generan, a través de una distinción entre los malos poetas y los que, como a él, inspiran las Musas, de cuya autenticidad da prueba la calidad de sus efectos en el receptor, a quien permiten evocar una visión intrínsecamente superior a la mundana y ser semejante a los dioses (una pretensión que, como veremos, resulta aún fundamental para Platón).

Este vínculo (y su potencial beneficio público) se mantiene todavía intacto en dos grandes poetas del siglo v, Píndaro y Esquilo, fundamentalmente porque ambos asumen los dos presupuestos básicos de la poética arcaica: que la poesía es un don divino $\mathrm{y}$, por tanto, verdadera, y que el lenguaje adquiere la naturaleza ética de lo que describe. La diferencia entre sus respectivas poéticas viene dada, sin embargo, por una concepción distinta de la mirada que la divinidad proyecta sobre el mundo humano, y de cómo debe el poeta desplegarla a través de su estilo y contenido poéticos.

Para Píndaro, la experiencia humana se presenta bajo una caótica mezcla de crimen y virtud, una parte de la cual (la negativa) carece de realidad desde la perspectiva divina, porque no responde a su piadoso plan (kairós). Bajo este punto de vista, el kairós no es sólo lo mejor, sino lo único verdaderamente cognoscible; y el cometido del poeta, como sophós, consiste precisamente en permitir que aflore ese plan divino, borrando la maldad con el silencio ${ }^{2}$. Su sabiduría, gobernada por la piedad (aidós) ${ }^{3}$, preserva una verdad restringida (la memoria de la virtud triunfante), que desvela el rastro radiante de los dioses en el mundo, e inspira en sus oyentes la conciencia de su propia virtud y el afán de mejorarla. Aunque la habilidad del poeta para conseguir tal efecto es limitada, porque el receptor entiende sólo en la medida en que se lo permite su naturaleza: Píndaro es maestro de virtud, pero la virtud que muestra no puede aprenderse $(O .9 .100-102)$. Por ello, su canto se presenta como un medio de relación social que celebra un estado de concordia y de placer compartidos $(O .7 .1-12)$, con el que pretende vincular (y vincularse) únicamente a hombres virtuosos, capaces de responder a los imperativos de un éros moderado que se colma cumpliendo una «recta cantidad» de deseo (N. 8. 4s.); la transgresión de sus límites lo convierte en una esperanza excesiva y vana que se manifiesta en una disposición envidiosa hacia los demás hombres (phthónos) y en la inevitable corrupción de las relaciones sociales.

\footnotetext{
${ }^{1}$ Cassirer (1971: pp. 63ss.)

${ }^{2}$ «La verdad exacta / no es más provechosa cuando muestra su cara / y el silencio es a menudo lo más sabio para un hombre» $(N .5,16-18)$.

${ }^{3}$ Para la traducción del término, así como para la interpretación del programa poético de Píndaro, véase Walsh (1984: pp. 37-61).
} 
Tal es la representación, bella y parcial, de la experiencia humana que elabora Píndaro a través de un lenguaje que él define como simple, en la medida en que surge naturalmente de la verdad de lo que nombra, y no precisa de abigarrados artificios para disfrazarla o violentarla; y cuya invención asume parcialmente $(O .9 .80)$, porque la poesía es, al fin y al cabo, un hallazgo que procura la divinidad ${ }^{4}$.

Parecidos presupuestos encontramos en Esquilo, para quien la complejidad del mundo es, en cambio, resultado de la proyección de una mirada divina igualmente compleja e irreductible para el hombre. Por eso sus tragedias representan la totalidad de la experiencia humana por medio de un lenguaje contradictorio y ambiguo, que, sin embargo, ofrece también (como hacía Píndaro con el propio) como garantía de verdad. Esquilo comparte con Heráclito el uso profuso de metáforas y oxímora, una figura que transgrede las definiciones léxicas y cuyo potencial significativo se nutre de una mentalidad que todavía cree en la conexión mágica entre las palabras y las cosas que designan. El lenguaje refleja automáticamente la naturaleza del mundo: el sentido está inherente en el sonido de las palabras; sonidos similares denotan cosas similares, o combinadas armónicamente, de manera que el término positivo y el negativo de un oxímoron poseen una identidad que el significado lógico niega. Pero no es posible eliminar ninguno de los dos, ni hacer una traslación del lenguaje figurativo al literal, porque las interpretaciones parciales violan la esencia de esta figura; aceptar su complejidad significa asumir la complejidad del mundo. El único modo de entender este lenguaje es someterse pasivamente a su hechizo, dejar que los sonidos arrastren los sentidos adecuados y que la emoción abra la vía a la comprensión.

Esta riqueza estilística resulta particularmente notable en el Agamenón, la primera parte de la trilogía de la Orestíada, donde la naturaleza misma de la familia de los Atridas genera su descripción a través del oxímoron: el crimen de Atreo instala en su universo, aparentemente para siempre, la contradicción y la complejidad, y destruye la posibilidad de actos y definiciones simples. Por otra parte, un implacable y no menos complejo sistema de justicia divina, niega a quienes participan de ella una definición inequívoca, simple y distintiva, de su identidad individual; lo cual se manifiesta especialmente a través del entramado de metáforas que, combinadas, producen en esta obra una red de semejanzas y asociaciones que hacen que cada cosa sea identificable con cualquier otra, y que cada personaje sustituya a otros, afirmando la identidad de las generaciones y la perpetuación del ciclo de crimen y castigo.

El fin de la maldición pasa por definir acciones y agentes en sus limitados términos propios, con simplicidad, de forma que el bien pueda ser nombrado sin el mal concomitante. Y a esta necesidad responde, sin duda, la simplificación del lenguaje perceptible en Euménides, que podría entenderse como fruto del esfuerzo del poeta por liberar a su público de ese temible mundo gobernado por la metáfora en el que lo ha comprometido 5 , y por enseñarle que la justicia es, como decía Heráclito, lucha.

Pero esta confianza en la verdad de la palabra poética, garantizada por su naturaleza sacra, y en su poder para mejorar la convivencia política, queda irreparablemente

\footnotetext{
${ }^{4}$ «Mi lengua quiere apacentarlo,/ pues con ayuda de la divinidad/ florece el hombre en sabios pensamientos» (O. XI, 8-10).

${ }^{5}$ Walsh (1984: pp. 62-79).
} 
dañada por la teoría gorgiana del Lógos: el lenguaje como tal (y no exclusivamente el poético) se convierte en una téchne que, manejada con precisión por la razón humana, permite obtener esos fascinadores y persuasivos efectos (Helena, 10) que los poetas se han arrogado en exclusiva y atribuido al influjo divino. La poesía no es más que «un lógos que tiene medida».

Sin embargo, la fuerza demoledora de esta teoría radica, curiosamente, en lo que comparte con la concepción poética del lenguaje, que se manifiesta en su descripción de la psicología de la comunicación verbal como un proceso «mágico» (goeteía, Helena, 10$)$ que se nutre de la cuasi-sustancial naturaleza de las palabras: con un cuerpo diminuto e invisible, el Lógos cumple los más divinos actos (theiótata érga apotelê, Helena, 8); su impacto en el alma es irresistible (12), casi físico, como el de una droga en el cuerpo (14), porque la mente no experimenta las palabras como signos que describen cosas, sino como cosas en sí mismas, y sus efectos son, por tanto, independientes de su valor referencial. El lenguaje «hechiza» (éthelxe, 10) al alma pasiva, la «marca» (etypósato, 13), pues está por encima de la comprensión y de la interpretación, y puede incluso «hacer visible» (phaínestahi, 13) lo ininteligible.

La diferencia fundamental entre la teoría gorgiana del Lógos y su concepción poética, procede de su rechazo de la primitiva creencia de que la relación entre palabras y objetos está fijada naturalmente y, por tanto, de que las palabras reflejan mágicamente la verdad: para Gorgias, las palabras son experimentadas como reales por el pensamiento, pero difieren esencialmente de las cosas reales, por lo que engañan en todos sus usos. Así, el encantamiento poético y el argumento filosófico se convierten en el mismo arte engañoso (apáte). Tampoco habría, en consecuencia, una diferencia sustancial entre los efectos psíquicos de la primera y la tercera persona narrativas, o entre los de la narración y la representación dramática. Si tenemos en cuenta, además, que «quien engaña es más justo que el que no engaña, y el engañado más sabio que el no engañado» (fr. 23), hemos de deducir que el tipo de engaño que urde el lenguaje en general no es necesariamente no verdadero, y que, de este modo, quedan borradas, definitivamente y a todos los efectos, las fronteras entre su uso poético y su uso dialéctico.

Esta afinidad entre la concepción gorgiana de las palabras como objetos «autónomos» del pensamiento, y el uso mágico retórico que hacían los poetas del lenguaje, la explota Aristófanes en las Ranas identificando literalmente ambos puntos de vista en el programa poético de su Esquilo ficticio, y poniendo esto en conflicto con la perspectiva moderna, personificada en Eurípides, cuya estética y moralidad están basadas en una noción formal y analítica del lenguaje. Al final de la obra, las palabras de los dos poetas se pesan en una balanza, y es Esquilo quien gana la competición. Desde su perspectiva, la debilidad del arte de Eurípides radica en su insustancialidad espiritual: sus palabras no «pesan» porque carecen de noûs (v. 1396), y pueden ser manipuladas según criterios puramente formales, puesto que el órgano que las crea es la lengua (vv. 826, 829); en cambio, él crea con el aliento de sus pulmones (v. 829 ) un lenguaje que es «igual» (isa) a los pensamientos que expresa (vv. 1058s.), y dice únicamente lo que siente, mientras que Eurípides hace posible una nuevo tipo de engaño (vv. 1083-88), que es el reverso de la apáte gorgiana, ya que se basa en la separación, más que en la identidad, entre lenguaje y sentimiento. Esta es también la razón por la que la poesía euripidea parece incapaz de procurar placer, y por la cual 
Dioniso, que comienza su viaje al inframundo con una pasión ambiguamente intelectual por él, prefiere finalmente a Esquilo: el lenguaje de Eurípides es, sin duda, innovador (v. 99) y sofisticado (v. 906), pero carece de la simplicidad y del contenido moral del lenguaje «pasado de moda»: no sale del alma del poeta, ni afecta a la de su público.

La explicación que da Eurípides de la función del lenguaje, y de las virtudes y defectos de la poesía, asume que las palabras no son cosas en sí mismas, ni poseen, en rigor, sus cualidades: son signos de las cosas que transmiten información sólo al referirse a ellas «correctamente» (orthótes tôn epôn, v. 1181), es decir, con precisión referencial. Su alternativa a la creatividad de Esquilo es la «destreza» (dexiótes), una cualidad explícitamente asociada al uso de libros (vv. 944 y 1114), de manera que podemos entender este agón como una reflexión sobre un conflicto más amplio entre cultura oral y cultura «literaria» (vv. 1408-11), o entre dos generaciones, la primera de las cuales ha experimentado la poesía casi exclusivamente a través de la recitación, mientras que la segunda ha aprendido a determinar su significado a través del código abstracto y formal del alfabeto fonético ${ }^{6}$. Este conflicto será también un motivo recurrente en los diálogos platónicos: el Sócrates del Fedro, por ejemplo, revive los viejos valores y evoca a Esquilo cuando muestra su preferencia por la locura (243c, 244a y ss.) y la sinceridad (spoudé, 276c) de la palabra oral, inspirada por el aliento vital, en detrimento de la poco auténtica escritura.

Eurípides y Esquilo coinciden únicamente en que los poetas pueden hacer a los hombres mejores (vv. 1008-12), pero sus puntos de vista sobre la vida moral y política difieren tan radicalmente como los que afectan al lenguaje y a la psicología de la comunicación. Según Esquilo, el carácter moral se insufla directamente al alma pasiva del espectador, que queda «estampada» por las palabras (cf. Helena 13, 15): por eso atribuye a sus personajes una dicción acorde con su êthos: noble, simple y homogénea, semejante a la música que la acompaña (vv. 1059-62); y considera moralmente sospechosa la escritura «indiscriminada» de su rival. Si el público asume y reproduce las cualidades de los personajes que actúan en escena, el poeta enseña la maldad simplemente representándola o describiéndola, y está, por tanto, obligado a ocultar lo que es perverso (vv. 1053s.). Tal era, también, la opinión de Píndaro, como lo será después la de Platón.

Eurípides, por el contrario, tiene plena conciencia de lo que actualmente denominamos «distancia estética», y alega simplemente que sus historias son reales (ónta, v. 1052), y que, como tales, no pueden perjudicar al espectador; él no se jacta, como hace Esquilo (y el propio Aristófanes en la parábasis, vv. 718-22 y 726), de haber «acuñado» buenos ciudadanos: no pretende moldear las almas, sino proporcionarles material y métodos de análisis (vv. 959ss.).

Los términos morales de este argumento sobre la influencia de la poesía se trasladan seguidamente a los políticos. La cuestión más importante a este respecto concierne a la distribución del poder en la ciudad que su actividad literaria implícitamente favorece. Este problema determina el último y decisivo estadio de la contienda, y nos

\footnotetext{
${ }^{6}$ Ronchi, (1996: pp. 24-26, 33-37 y 46-49).
} 
ofrece la mejor aproximación a lo que Aristófanes pudo haber pensado sobre su propio papel como poeta que ejerce su arte en ausencia de los dos contendientes trágicos.

En la imaginación de Aristófanes, el impresionante y portentoso lenguaje de Esquilo pertenece también a un cierto tipo de orador ateniense, especialmente a Pericles: él sabía (como Homero, Píndaro y Esquilo) entusiasmar a sus oyentes y manipular sus emociones (Thuc. 2.65.1), cambiar su confianza en miedo y viceversa (Thuc. 2.65.8-9; cf. Helena, 14), con un vuelco irracional (Thuc. 2.65.9) que nos recuerda a la «confusión» de Gorgias (etaráchthe kaì etáraxe, Helena, 16) y de Esquilo (Ra. 962). Sus discursos permitieron a los ciudadanos mirar más allá de los condicionamientos presentes, ofreciéndoles una perspectiva de mayor alcance que les ayudó a mantener su unidad por encima de los intereses particulares divisorios (Thuc. 2.65.7).

El arte de Eurípides, en cambio, alimenta una igualdad de competencia intelectual activa, más que una aquiescencia pasiva (vv. 954ss.); y, aunque parece más democrático en su espíritu (v. 951), es divisor en sus efectos, pues sus lecciones conciernen a los asuntos privados del espectador (v. 959), que resultan, a la postre, incompatibles con la cooperación social.

Al elegir a Esquilo, Dioniso parece aprobar la afinidad literaria y política del poeta con Pericles; pero el criterio de su opción es poco claro, y sugiere la propia ambivalencia de Aristófanes respecto al tema. En efecto, como última prueba, Dioniso solicita a los contendientes su punto de vista sobre Alcibíades y la salvación de Atenas. Los dos ofrecen básicamente la misma propuesta para salvar la ciudad, que coincide, por otra parte, con la que el propio Aristófanes ha dado en la parábasis (cf. vv. 734s., 1446-50 y 1454-59). Pero, a partir de este momento, se derrumban los parámetros antitéticos por los que ambos poetas han sido definidos, y cada uno de ellos adquiere las virtudes y los defectos del otro.

Si Aristófanes no ratifica plenamente el arte de Esquilo y los valores políticos con él asociados, podemos pensar que lo adopta como parte de una síntesis ideal que aúne los valores, y esté libre de los vicios, de ambos poetas: una poesía compuesta en un lenguaje del espíritu, pero preciso y eficaz, comprometido con las necesidades prácticas, capaz de producir un pueblo reflexivo y libre, pero unificado y lleno de coraje. De hecho, estas son las cualidades de las que se jacta Aristófanes cuando afirma de sí mismo que es diestro, como los sofistas amigos de Eurípides ( $N u$. 547), y nunca engaña a su público diciéndole dos veces la misma cosa (Nu. 546s. y $V$. 1051-54); pero tampoco enseña argucias, ni sucio comercio (Ach. 657s.), sino que eleva su arte construyendo un gran edificio de pensamiento y forma (Pax, 749s.), como Esquilo ( $R a .1004)$, para crear un público de curtidos marinos (V. 1094ss.; cf. Ra. 1071s. $)^{7}$.

No muy distinta, en el fondo, a la percepción aristofánica de esta crisis, fue la que tuvo el Eurípides real, en cuyas obras (particularmente en la Antiope) se oponen también dos modelos poéticos: uno «transmundano», «fascinador», que procura a su público calma y evasión eludiendo las realidades contingentes, pero a consecuencia de lo cual resulta irrelevante para la experiencia mundana; y otro que, por el contrario, se nutre de motivos exclusivamente humanos, y exige un receptor activo y autoconscien-

${ }^{7}$ Walsh (1984: pp. 85-98). 
te, pero de cuyo placer se desentiende. Y manifiesta idéntica conciencia del menoscabo que supone para la validez de ambos la quiebra de la vieja unidad de objetivos.

La estética de la poesía «hechizadora» tal como Eurípides la entiende, puede reconstruirse a partir de un grupo de textos fragmentarios que han sido asociados, con más o menos certidumbre, a la perdida Antíope. Anfión, su protagonista, se presenta como prototipo del hombre no mundano, devoto de la poesía de puro encantamiento que desciende de Homero, pero que se ha visto radicalmente alterada por el signo de los nuevos tiempos: en efecto, él comienza excluyendo de su poesía los males de la ciudad (fr. 202), las cuitas particulares de los hombres del momento, y acaba evitando como motivo poético cualquier tipo de experiencia humana; elige como tema a unos dioses despojados de sus cualidades humanas, convertidos en símbolos de sustancias cosmológicas impersonales, para ofrecer a su público la fascinadora visión del «orden intemporal de la naturaleza inmortal» (frs. 910 y 911).

Anfión lleva a cabo esta depuración de la materia poética porque asume los tradicionales presupuestos de que la experiencia humana es mixta (fr. 196), y de que el público «vive» directamente lo que la poesía representa. Un canto en el que quede vestigio de esa mezcla no puede complacer al oyente, a quien pretende liberar, como a sí mismo, del contacto con los asuntos humanos, fuente de toda preocupación: la verdadera felicidad, independiente de la inestable fortuna, es inmaterial (fr. 198), y puede recrearse en el canto (fr. 193).

Las críticas que plantea Eurípides a este modelo poético son básicamente dos: una, la expone la nodriza de Medea (vv. 193-203), cuando niega que la poesía pueda proporcionar algún tipo de placer superior a los materiales, o compensar su pérdida; la otra, Zeto, el hermano de Anfión, para quien la fascinación poética hace a los hombres olvidar lo que tienen de valioso en sí mismos. El único beneficio que este tipo de poesía puede aportar, es un placer contemplativo de efectos efímeros, que tiene como contrapartida el «autoabandono» del receptor, (frs. 186 y 187), la incapacidad para conseguir su propia clase de excelencia, la cual se proyecta más allá del placer, y surge únicamente de su relación con el mundo material (fr. 184). El valor de la poesía depende, para Zeto, de su implicación en lo mundano (fr. 188), y de su utilidad práctica como reflejo de la vida (fr. 185) ${ }^{8}$.

Ahora bien, el modelo que propone Zeto es también objeto de serias críticas en Medea, donde el coro femenino (vv. 421-430) reprocha a los poetas varones que lo han practicado el haber violado la exigencia de fidelidad a la verdad (puesto que han calumniado a las mujeres para ocultar los errores masculinos, haciendo una falsa representación de los vicios y virtudes humanos), y corrompido su arte usándolo como instrumento de ambición partidista. Para el coro (vv. 627ss.), la poesía debería alejar a los hombres del éros excesivo que promueve insaciables rivalidades (vv. 627-41), y ser fuente del influjo de un éros moderado, que los convierte con su hechizo en seres pacíficos y honestos: así ocurre en la Atenas ideal que imagina el coro, donde las Musas han dado a luz a Armonía (vv. 830-32), y sustenta al público el arte del poeta

8 Para Gentili (1996: pp. 89-91), la crítica de Eurípides afectaría en realidad a toda la poesía precedente, más atenta al placer del canto que a la necesidad de profundización dialéctica exigida por la concepción ética del poeta como maestro de verdad y de sabiduría. 
que practica la poesía encomiástica verdadera (sophía). La sociedad ateniense exhibe la doble influencia de este arte complejo, que abarca en su equilibrio lo mundano y lo trascendente: Atenas es un lugar donde triunfa areté (la excelencia conseguida, vv. 844s.), fruto de la colaboración entre éros y sophía; el hechizo que opera en ellos no los abstrae, como a Anfión, de la realidad del éros mundano: preserva la conciencia de la propia condición, pero liberada del deseo obsesivo por las cosas materiales que impide conseguir la virtud (vv. 627-30), y permite sacar provecho de la lucha entre tendencias humanas opuestas.

No hace falta señalar hasta qué punto recuerda esta descripción de la influencia de Afrodita en las relaciones sociales a la que hacía Píndaro. Hemos de suponer que, para Eurípides, una poesía ideal sólo puede resultar del equilibrio entre la búsqueda del desapego absoluto de lo mundano y la de la satisfacción de los deseos materiales; y debe asumir como tema por excelencia la areté, una experiencia humana arraigada en el mundo, que proporciona un motivo poético realista y útil como guía de conducta, pero que trasciende, al mismo tiempo, el deseo mundano (vv. 627-30). Al igual que sucedía en la poética de Píndaro, la especial condición de la areté la convierte en prueba de las cualidades artísticas y éticas del poeta, que sólo conseguirá ese canto ideal si ha conciliado en su interior los impulsos dispares de la mundanalidad y la evasión de lo mundano?.

III. Ahora trataremos de demostrar cómo la reflexión platónica sobre la poesía es en buena medida una continuación de este debate que se plantea en Ranas y Antíope, y cómo la evolución de su pensamiento puede interpretarse como una sucesión de intentos por ofrecer soluciones propias a un conflicto que cobra para Platón importancia creciente a medida que se va imponiendo su vocación política. En consecuencia, habrá que examinar los diálogos respetando el orden cronológico en que fueron escritos, porque el transcurso del tiempo modifica, si no la naturaleza de los temas sobre los que se sostiene la crítica poética, sí la perspectiva desde la que se examinan, su grado de complejidad y elaboración y, por supuesto, sus conclusiones. Tampoco está de más recordar que Platón admiraba a Aristófanes y Eurípides ${ }^{10}$, y que tomó el debate de la Antiope como modelo para el que sostienen Calicles y Sócrates en el Gorgias ${ }^{11}$.

Las observaciones de Platón sobre la poesía se diseminan en muchas de sus obras, pero aquí nos centraremos únicamente en aquellas que abordan la cuestión de un modo más amplio, directo y comprenhensivo, y conducen a conclusiones de esa misma índole: Ion, Fedro, República y Leyes. Sin embargo, traeremos también a colación reflexiones de otros diálogos cuando maticen, amplíen o clarifiquen las de estos que abordamos.

1. El primer diálogo que Platón, en plena juventud, dedica a la poesía, es el Ion, el único de su producción en el que este tema se aborda de manera independiente y exclusiva, y se centra en torno a dos motivos: la naturaleza de la inspiración poética y

\footnotetext{
${ }^{9}$ Walsh (1984: pp. 107-116).

${ }^{10}$ Colli (2008: pp. 48s.).

${ }^{11}$ Collard (2004: pp. 259s.).
} 
la relación entre poesía y téchne (533c-535b). Ambas cuestiones están, como veremos, íntimamente vinculadas. Por lo que respecta a la primera, Platón atribuye la causa de la poesía a la intervención de una fuerza divina (theîa dýnamis) en el alma del poeta (534b), al que informa mediante el enthousiasmós (533d-e). Aunque resuena en sus palabras el eco de las de Demócrito (frs. 18 y 21) (2) $^{12}$ las observaciones de Platón están, por su imprecisión y vaguedad, más próximas a las concepciones tradicionales sobre este fenómeno que a la teoría del atomista. En cualquier caso, resulta obvio que lo que a Platón le interesa colegir de aquí es que la poesía no está, por su propia naturaleza, al alcance de un saber humano ${ }^{13}$, y no puede, por tanto, ser téchne, ni transmitir verdades abstractas racionales (532a-e).

Esta conclusión le permite «despachar» dos problemas de complejísimo alcance: niega, por una parte, el valor que la poesía ha tenido hasta el momento como medio de formación ética y política; y por otra, la «tecnificación» que hace la sofística del «don» poético, junto con sus pretensiones pragmáticas e interesadas respecto a este arte. La justificación de ambas negaciones se aborda nuevamente en el Protágoras (338e-348a), donde Sócrates «demuestra» con un ejemplo concreto (la discusión sobre el conocido poema de Simónides sobre la virtud), no sólo que la poesía no es en sí misma un medio de aprendizaje digno de confianza, sino que, además, su interpretación crítica con fines pedagógicos corrompe su verdadera naturaleza.

En ello resulta determinante el hecho de que el Ion es un diálogo todavía muy condicionado por las ideas socráticas. Antes de conocer a Sócrates, Platón, cuya naturaleza «tendía más a lo locura heroica que a la sophrosýne y la politicidad helénica», se había entregado a la manía poética, pero él «cambió su sensibilidad, podría decirse, y le hizo odiar la poesía» ${ }^{14}$. Tras su desaparición, sin embargo, comienza para Platón una profunda transformación, y se manifiesta entonces su naturaleza presocrática y dionisiaca, que es, en realidad «antipolítica», en la medida en que centra su impulso en la búsqueda en la propia interioridad, y en la superación de todo lo que es humano ${ }^{15}$.

El diálogo que señala el inicio de esta crisis es, precisamente, el que dedica a Gorgias, el sabio que clausura la era de los sabios, cuya teoría del Lógos desacraliza la poesía e inhabilita la dialéctica como instrumento de conocimiento, dejando a ambas a merced de intereses partidistas. No es ya el Sócrates histórico quien habla en el Gorgias, sino Platón, expresando «la ira contra los hombres que amenazaban sus más bellas aspiraciones y, por último, un descorazonamiento que es casi escepticismo, tal como se revela en la actitud negativa del diálogo, que tiende sobre todo a destruir la retórica y los métodos políticos de la democracia ateniense. $\rangle^{16}$

2. Cuando Platón revisa el tema de la poesía, está ya en plena madurez, y lo hace, de manera muy diversa y con muy distintas conclusiones, en dos diálogos: La Repúbli-

${ }^{12}$ Lledó (1961: pp. 61-65).

${ }^{13}$ «Todos estos hermosos poemas no son de factura humana ni hechos por los hombres, sino divinos y obra de los dioses» (534a).

${ }^{14}$ Colli (2011: p. 144).

${ }^{15}$ Colli (2011: pp. 40-43).

${ }^{16}$ Colli (2008: p. 62). 
ca y el Fedro, que la mayoría de los estudiosos ubica cronológicamente en este orden. Nosotros, sin embargo, creemos justificada la datación inversa.

El principio central del discurso del Fedro es una alabanza de la locura dionisiaca en sus diferentes aspectos, exaltada como lo que de más divino hay en el hombre. Esta es la afirmación anti-socrática más audaz de Platón: la manía es reconocida como superior a la sophrosýne, y, «junto a la nueva manía amorosa, permanece la manía de purificación, ..., y además se proclama por primera vez como divina la locura poética. Con el amor,... vuelve a aparecer el impulso poético que está siempre en el fondo de su alma, y que tiene ahora la posibilidad de expresarse no ya en la forma pasional y humana de la tragedia..., sino a través de un arte divino que habla con imágenes de la verdad..${ }^{17}$

De la coexistencia de esas tres locuras nace un fenómeno tan especial como el amor platónico, una pasión todavía completamente transhumana en el Fedro, punto de unión entre lo humano y lo divino (253e-254b). Precisamente este vuelco desde la propia interioridad hacia una interioridad ajena, hace a Platón centrarse en el problema de la educación, que se convertirá en el punto esencial de su política. El Fedro marca el comienzo de esa transformación del éros contemplativo en éros pedagógico que culminará en el Simposio, y cuyos efectos en la vida social - liberar al individuo del phthónos y del egoísmo que corrompen la actividad política humana, haciéndole partícipe de lo divino (249c) - son descritos por Platón en términos que tanto recuerdan a los utilizados por Píndaro y Eurípides para plasmar los efectos del canto ideal.

No es fortuito el hecho de que en este diálogo (244a-b) se revisen los dos motivos tratados en el Ión con respecto a la poesía (el de la inspiración y el de la téchne); pero ahora, Platón opone las creaciones inspiradas por las Musas al espíritu hapalén kaì ábaton del poeta, a la poíesis toû sophronoûntos, fruto de la téchne; y afirma:

Aquel que sin esta especie de locura se acerca a las puertas de la poesía, creyendo, en efecto, que por una técnica llegará a ser poeta, se esfuerza inútilmente, y su poesía, creada en plena razón, será oscurecida y anulada por la de aquél que creó bajo la locura de las Musas (243a, 5-8).

Resulta obvia la evolución que ha experimentado con respecto al Ion el concepto de téchne, que no implica ya en este diálogo una idea de la comprensión total de la realidad en sí misma, sino un conjunto de reglas dadas por el hombre sobre la base de un conocimiento superficial y mecánico de la misma. Si en el Ion se niega a la poesía el conocimiento de lo general, en el Fedro parece concebirse como un método de conocimiento, capaz de superar el saber que comunica la téchne, y de llegar a las verdades abstractas ${ }^{18}$.

En mi opinión, la oposición que establece aquí Platón entre estos dos tipos de poesía es básicamente la misma que planteaban Eurípides y Aristófanes, aunque difiera la clave expositiva, que no es en el Fedro analítica y dialéctica, porque Platón desprecia

\footnotetext{
${ }^{17}$ Colli (2011: p. 173).

${ }^{18}$ Lledó (1961: p. 68), y Nussbaum (1995: p. 291).
} 
a los poetas «técnicos», y no se plantea una posible síntesis entre dos modelos poéticos antagónicos, pero cada uno con su propia validez. Esta opción, por otra parte, es perfectamente coherente con su concepción del éros como una pulsión contemplativa, no mundana, cuya aprehensión exige una vía de la misma índole. Y cuando, transformado en pedagógico, se convierta en punto de conexión entre el deseo humano más común y el paradigma de la creatividad divina en el kósmos, ansia correcta de belleza que transfigura el deseo y lo vuelve realista, moral ${ }^{19}$, no aceptará que su búsqueda pueda encauzarse a través de la «dialéctica» poética, sino de la política.

3. De hecho, la visión del Fedro cambia radicalmente en La República, el diálogo platónico donde encontramos un análisis más profundo de la poesía, que se examina desde una perspectiva pedagógica en los libros II y III, y desde una perspectiva ontológica en el X; y donde queda desprovista de su aureola divina (Mas, p. 7). La índole de sus conclusiones al respecto nos hace pensar que, frente a la opinión mayoritaria, tienen razón quienes estiman que este diálogo es posterior al Fedro. Según Colli (2008: pp. 98-104 y 117), vio la luz en el 375 como un todo orgánico, y la intención de Platón era influir directamente en la vida práctica, pues creía en la posibilidad de realizar su estado, «una institución educativa en la que el individuo es conducido mediante el éros al conocimiento de la idea suprema».

De acuerdo con este objetivo, a propósito del programa de educación de los niños de la clase de los guardianes ( $R$. 376-412), Platón examina tanto el contenido como la expresión formal de los géneros poéticos más antiguos. Respecto a la primera cuestión, concluye que hay que silenciar (málista mèn sigâsthai, 378a 3-4) la mayoría de los mitos de Homero y Hesíodo, incluso aunque fueran verdad (378a 2), porque ofrecen unos modelos de excelencia que en absoluto contribuyen a que los jóvenes «sean piadosos y que su naturaleza se aproxime a la divina todo cuanto le está permitido a un ser humano» (383c); por el contrario, minan la valentía (386a-c) y el autocontrol (387d-e, 389d-390c), y justifican todo tipo de debilidades (391d-392a).

Cuando aborda la cuestión de la léxis (392c-398b), Platón define la poesía como un relato de cosas pasadas, presentes o futuras (392d 2), que puede hacerse haplêi diegései è dià miméseos gignoménei è di' amphotéron (392d 6-7). En el segundo caso, el poeta es también intérprete (además de «narrador»), y la diégesis se convierte en mímesis: la narración se logra por medio de la representación (dià miméseos tèn diégesin poioûntai, 393c); los personajes actúan y aparecen como envolviendo la personalidad del autor, dando un matiz muy especial a su léxis, y provocando a la vez en el receptor una misma instancia de identificación con lo representado. La mímesis designa, por tanto, el medio de expresión, la interpretación por parte del actor, y la situación de aprendizaje por parte del receptor.

De esta distinción surge la clasificación tripartita de la poesía (394b-c), la primera clasificación de géneros conocida, que supone, en mi opinión, por un lado, la aceptación de parte del contenido de la teoría gorgiana del Lógos (el que concierne a la psicología de la comunicación verbal, que no difería mucho, en cuanto a la concepción de sus efectos en el receptor, del que atribuían los poetas tradicionales al poder má-

\footnotetext{
${ }^{19}$ Murdoch (1982: pp. 44ss.).
} 
gico del lenguaje), cuya fascinación en el alma pasiva del oyente describe Platón en términos de mímesis (hai miméseis...eis éthe te kaì phýsis kathistantai kaì katà sôma kaì phonàs kaì katà tèn diánoian, 395d); pero también una réplica a la indiferenciación de Gorgias entre modalidades de discurso y a su afirmación de que el lenguaje es apáte en todos sus usos. En efecto, al margen de ese hechizo que Platón interpreta negativamente - al igual, paradójicamente, que los poetas que asumían en su programa la perspectiva «sofística» de que el lenguaje es un medio de descripción neutro, y preferían a un público «desencantado», que valorara la claridad y el pragmatismo-, quedarían, no sólo el discurso dialéctico, sino también la poesía no mimética, que puede aún salvar (398a-b).

Seguidamente, examina Platón las formas artísticas no verbales o musicales (398c402d), y expone el principio de que la música debe seguir a la letra (kaì mèn tén ge harmonian kaì rhythmòn akoloutheîn deî tôi lógoi, 398d), y de que han de rechazarse los ritmos multiformes y complejos que imiten disposiciones de ánimo negativas, aceptándose únicamente los que imiten a héroes virtuosos y prudentes (399e-400a). Porque «la bella dicción, armonía, gracia y eurritmia no son sino consecuencia de la simplicidad del carácter (euetheía)... realmente adornado de buenas y hermosas prendas morales» (400e).

Si examinamos la argumentación platónica, podemos observar que en ella se asumen algunos de los principios clave de los poetas tradicionales: la selección de la materia poética y la censura de los mitos homéricos había sido ya activamente practicada por Píndaro, quien optaba, como Platón, por el silencio (cf. N. 5, 16-18, y R. 378a 3-4); el Esquilo ficticio de las Ranas afirmaba igualmente que el poeta debe ocultar la maldad, puesto que el mero hecho de representarla o describirla implica enseñarla (vv. 1053s.); y el Anfión euripideo ofrecía al receptor en su poesía la fascinadora visión de «el orden intemporal de la naturaleza inmortal» (fr. 910) purificado de todo lo humano, incluidos los dioses homéricos.

Lo mismo podemos decir de la necesidad de adecuación entre lógos y métron, y del rechazo de la mezcla y la complejidad formales: es lo que proclama el Esquilo de Aristófanes (Ra. 1059-62), cuando afirma que música y dicción poéticas deben ser homogéneas, y ajustarse a un único e indiferenciado medio virtuoso, a una simplicidad que, como sostenía también Píndaro (N. 8, 32-4), es garantía de virtud en el emisor, en el mensaje y en el receptor. Bajo esta exigencia platónica, late la sospecha de que el lenguaje poético adquiere la naturaleza moral de lo que describe, y con ella «acuña» el alma «pasiva» del receptor, que lo integra acríticamente en su experiencia vital: en tales términos se han expresado Aristófanes ( $R a$. 718-22 y 726), su personaje de Esquilo en las Ranas, y el propio Gorgias (Helena, 13), cuya teoría del Lógos asume Platón de modo restrictivo, aplicándola exclusivamente a la poesía mimética.

No podemos tampoco olvidar que, en el Crátilo, Platón ha puesto ya frente a frente las dos teorías opuestas del lógos que surgen como resultado de la escisión de los dos motivos que Heráclito contempló como unidad (la doctrina de la identidad de la palabra y el ser, y la de la antítesis entre palabra y ser), y ha rechazado ambas, en su totalidad o en parte. La teoría del lenguaje como fruto de una convención más o menos arbitraria y susceptible de una posible revisión, defendida por los sofistas, que toman de ese dominio intermedio de las palabras que se encuentran entre la realidad «objeti- 
va» y la «subjetiva», sus mejores armas para defender la relatividad del conocimiento, la desecha Platón ante la evidencia de que el lenguaje no puede modificarse arbitrariamente, porque expresa una forma de unidad, una comunidad de modos de relacionarnos con las cosas, que constituyen la base de nuestra propia actividad: manipular el lenguaje implicaría privarnos de nuestra propia posibilidad de actuación.

Pero tampoco puede aceptar ya la teoría de la correspondencia natural entre palabra y realidad, representada por Crátilo, para quien las palabras expresan y contienen la esencia de lo que nombran: la identidad heraclitea entre el todo del lenguaje y el todo de la razón se transfiere ahora a la relación de la palabra aislada con su contenido eidético, y esta transferencia hace insostenible la relación natural entre ambos, que Platón definitivamente desecha en su forma ingenua: él acepta la relación, pero la entiende como mediata y compleja, y no conseguirá definirla hasta el final de su vida, en la Carta VII ${ }^{20}$.

En medio de esta incertidumbre, Platón opta por una vía intermedia con respecto a la poesía, que pasa por clasificarla de acuerdo con sus modalidades de discurso, las cuales se definen en torno a la mímesis, cuya presencia o ausencia determina fundamentalmente la naturaleza de sus efectos en el receptor. Si es ella la causa del abandono emocional del oyente, eso significa que puede salvar la poesía no mimética, porque su mensaje es «simple», en la medida en que ofrece, de forma explícita y selectiva, un único modelo de conducta, evitando identificaciones indiscriminadas y confusas, y procurando que la disposición de receptividad emotiva incondicional del oyente actúe sólo en su propio beneficio.

En el libro X, sin embargo, Platón vuelve a examinar la poesía desde el punto de vista que aporta la teoría de las Ideas, y su crítica recibe una fundamentación ontológica, que se sostiene sobre la revisión del concepto de mímesis (595c) tal como ha sido presentado en el libro III, así como del concepto de téchne tal como ha sido tratado en el Fedro. Bajo esta luz, la obra de los poetas se torna indiscutiblemente perniciosa para el pensamiento de los que les escuchan $(595 \mathrm{~b}, 5)$. En efecto, cualquier téchne supone una actividad mimética cuya calidad se mide por su grado de relación con el ểdos (la esencia) de aquello que imita, el cual admite una triple jerarquía: el primer grado corresponde a la divinidad, que crea la esencia de las cosas (phytourgós); el segundo, al artesano (demiourgós); y el tercero, al artista (596b-597e), que toma como modelo para su actividad no el eîdos, como el artesano, sino la materialización que lleva este a cabo, y no produce, en consecuencia, cosas reales, sino simulacros de las mismas (598a-c).

Cuando se examina el resultado de la actividad poética desde esta perspectiva, la conclusión es idéntica: produce phantásmata, no ónta (599a), a los que no se puede seguir atribuyendo el valor cognoscitivo y pedagógico que les ha dado la tradición: «Todos los poetas, empezando por Homero, son imitadores de imágenes de virtud y de otras cosas que poetizan, pero no tocan la verdad» (600e).

Ahora bien, la razón de la decisión platónica de eliminar la poesía de su estado, radica, no menos que en la falta de «autenticidad» de su mensaje (consecuencia inevitable de la «incorrecta» perspectiva desde la que emisor lo elabora), en la clave desde la

${ }^{20}$ Cassirer (1971: p. 72). 
que exige ser interpretado por el receptor. El problema es resultado en ambos casos del «mal uso» de las palabras, los particulares chrómata (601a) con los que crea la poesía: ónoma y rhêma (cf. Helena, 9), aliados con métron, rhythmós y harmonía, hechizan al oyente (hoúto phýsei autà taûta megálen tinà kélesin échein, 601b 2-3, cf. Helena, 10), y acaparan toda su atención ek tôn lógon theoroûsin (601a7), en un ámbito significativo que trasciende el puramente referencial. Platón, como Gorgias, es de algún modo consciente de que el lenguaje poético, por su propia naturaleza, remite sólo a sí mismo, en un uso que lo neutraliza como instrumento de comprensión y conocimiento racionales, y que él concreta en los tradicionales términos de «hechizo» (kelouménois, $607 \mathrm{c} 8$; kelêi, 607d 1) que penetra en el alma (cf. Helena, 14) y la modifica, originando estados de tristeza o de alegría (è lypouménous è chaírontas, 603c) de una manera irracional. Esta disposición «pasional» que exige y promueve en el receptor la poesía, genera en él profundas contradicciones (603d), e «implanta privadamente un régimen perverso en el alma de cada uno, condescendiendo con el elemento irracional que hay en ella» (605b). La mímesis poética «riega y nutre en nuestro interior lo que había que dejar secar y erige como gobernante lo que debería ser gobernado a fin de que fuésemos mejores y más dichosos, no peores y más desdichados» (606d). Por eso, al igual que la parte inferior del alma debe estar subordinada a la superior, del mismo modo el poeta, cuyo vínculo con lo divino no ha vuelto a mencionar Platón, deberá someterse al filósofo ${ }^{21}$.

Esta nueva definición ontológica de la mímesis impone la necesidad de suprimir prácticamente la totalidad de la creación poética: lo único que Platón salva son los himnos a los dioses y los encomios de los héroes (607a). Su proceso «depurativo» recuerda extraordinariamente al que emprende Anfión en la Antiope, cuya poesía acaba ignorando cualquier tipo de experiencia humana (fr. 202) para ofrecer a su público la fascinadora visión de un mundo puro e inmaterial, libre de la inestabilidad mundana (frs. 198 y 193).

Platón sigue creyendo en la fuerza y la eficacia de la fascinación poética, pero, puesto que el poeta desconoce la verdad trascendente que vive tras las palabras (Mas, p. 9), necesita controlar el contenido y la forma de su mensaje, y, sobre todo, sus efectos en el receptor, al que, pese a todo, no desea expuesto al dudoso resultado de sus propios juicios, sino entregado a ese éros que permite «que su naturaleza se aproxime a la divina todo cuanto le está permitido a un ser humano» (383c).

Podríamos concluir que, si Aristófanes y Eurípides no lograron concretar la vía para alcanzar el equilibrio entre dos extremos deseables pero aparentemente irreconciliables en la práctica, Platón fuerza una falsa síntesis que consiste en optar por uno de esos extremos (el trascendente, no mundano), y suplir lo que le falta (su vínculo con la vida práctica, su «productividad» pedagógica) mediante el control del emisor y el receptor, depurando sus necesidades y expectativas hasta acomodarlas a su ideal de vida.

4. Creemos, además, que estas conclusiones están corroboradas por el contenido de su última reflexión sobre la poesía: la de las Leyes. Platón escribe este diálogo con sesenta y ocho años, y con el afán, según asegura Colli (2008, pp. 98-104) de propor-

${ }^{21}$ Mas (1992: p. 7). 
cionar a Dión un modelo justo y pragmático sobre el que articular un nuevo estado en Sicilia. Tras su último viaje a la isla, Platón ha perdido definitivamente la esperanza de poder educar a los hombres para el conocimiento. Pero, antes que abjurar de ellos y resignarse a la inacción, prefiere abandonar el ideal de la República: esta es, en el fondo, la más íntima justificación de las Leyes, que las palabras del propio Platón expresan sintéticamente: «En verdad, las acciones humanas no deben preocuparnos; sin embargo, es necesario ocuparse de ellas con pasión; lo cual no es un placer.» (VII, 803b).

Si en la República la realidad histórica se sacrifica al ideal, en las Leyes este se acepta únicamente en la medida en que puede coexistir con la realidad histórica. Y la realidad es que los hombres no están capacitados para la dialéctica: necesitan normas impuestas desde el exterior. La educación sólo servirá ahora para formar hábitos conforme a la legalidad; la religión y las leyes se convierten en los fundamentos del Estado, imponiéndose como principios que ordenan los impulsos opuestos de la condición humana ${ }^{22}$.

Modificados tan sustancialmente la naturaleza y el fin de la educación, Platón necesita revisar el papel de la poesía en la configuración de su nuevo modelo de Estado; y, junto con los temas clave de la República (la naturaleza mimética de la creación poética y la necesidad de valorarla bajo parámetros de verdad, la discusión sobre su valor pedagógico...), recupera otros deliberadamente excluidos de dicho diálogo, aunque recurrentes en los anteriores a él, como el de la antítesis entre la poesía fruto de la inspiración divina, y la que obedece a los imperativos de la razón práctica.

Nada más comenzar el libro II, el Ateniense (ya no Sócrates) acepta de modo sumario el papel pedagógico que con tanta persistencia se negó en la República a la poesía mimética $(653 \mathrm{c}, 654 \mathrm{a})$; y su discurso se centra en dilucidar la causa de su conflictiva relación con la ley, con el fin de procurar al Estado las vías e instrumentos adecuados para someterla y ponerla a su servicio. En efecto, si la poesía es mimémata trópon (655d), su valor no puede juzgarse por el placer que procura al receptor (655c-d), como afirma la multitud (kaitoi légousín ge hoi pleîstoi mousikês orthóteta eînai tèn hedonèn taîs psichaîs porízousan dýnamin), por ser este un criterio arbitrario, que depende del grado de adecuación entre el carácter que es objeto de la mímesis poética, y la naturaleza y los hábitos de quien la ejecuta o contempla (655d-656a). Como tal criterio arbitrario, puede y debe modificarse (656d-657b), «estableciendo por ley firme y confiadamente las melodías que se muestran rectas por naturaleza» (méle tà tèn orthóteta phýsei parechómena, 657c); entre otras razones, porque el placer de la multitud es caprichoso e indiscriminado (658a-e), y no todos los tipos de placer valen lo mismo: «... es la mejor Musa la que proporciona placer a los mejores y bien educados y principalmente a aquel único que se distingue entre todos por su excelencia y educación» (658e-659a). Este precisamente deberá erigirse en juez de la poesía para evitar que la masa ignorante y esnob corrompa «los placeres del teatro, porque sería necesario que el público, oyendo constantemente algo superior a su propio modo de ser, alcanzase un placer mejor, y según obra ahora, le ocurre todo lo contrario» (659c). Definido en términos positivos, su cometido consistirá en persuadir al poeta «y lo obligará si no lo persuade, a componer rectamente con ayuda de su dulce y escogido lenguaje, figuran-

${ }^{22}$ Colli (2008: p. 158-170). 
do en sus ritmos los ademanes y en su música los tonos de los hombres templados y valientes y enteramente buenos» (660a).

Ser justo y virtuoso es la condición de todo otro placer, y a esta máxima deberán ajustarse siempre lógos y métron poéticos (661 c y 662b); porque, incluso siendo mentira, resultaría útil y eficaz «para llevar a todos a obrar en todo con justicia, no a la fuerza sino voluntariamente» (663d-e).

La regulación de la práctica poética, tanto en lo que concierne al emisor y al mensaje, como en lo que concierne a sus receptores-ejecutores, organizados en tres coros, según la edad (664b-666e), permite ahora a Platón acogerla en todas sus modalidades, incluida la más productiva pedagógicamente (la mimética) y recuperar, sin las dolorosas renuncias de la República, la antigua unidad de los dos efectos ideales del canto quebrada por los poetas del siglo $\mathrm{v}(663 \mathrm{e}-664 \mathrm{a})$.

Lo que procede, entonces, investigar, en torno a la poesía y al placer (667b y ss.), es si ese efecto se busca justamente por sí mismo, con independencia de su rectitud y utilidad (667b-c) - lo cual sólo resultaría aceptable si lo que se juzga es mero juego (paidiá), nada digno de consideración (667e) —; o si deben contemplarse las otras dos variables. La respuesta viene determinada por la constatación de que la poesía es un arte mimético (668a-c), y como tal debe ser valorado por la rectitud de la imitación (miméseos orthótes), que consiste en «reproducir lo imitado en su cantidad y calidad» (668b); una capacidad de juicio que sólo está al alcance de quien conoce bien tanto la naturaleza del objeto de la mímesis poética como la de los medios verbales y musicales que mejor lo reproducen (668c-669b). Esta tarea estará reservada, en consecuencia, a los más viejos y sabios, cuyo cometido les exigirá ejercitarse en la práctica, el análisis y la selección de las armonías y ritmos (669b-670a) que mejor se adecuan a esa «Musa más hermosa que la de los coros y teatros públicos» (667a-b).

A diferencia de lo que ocurre en la República, en las Leyes Platón apenas se entretiene en la censura de la materia poética (probablemente porque se ejerce sin dificultad, 670a-b): su atención se centra ahora en la vigilancia de la «ortodoxia» formal (genérica, rítmica, musical), porque la mezcla y la sofisticación formales complican la tarea de captar con claridad cuál es el objeto de la mímesis poética, y cuál su calidad: en estas condiciones, «el que yerra puede producir más daño que nadie, encariñándose con temperamentos inmorales» (669b-c). Sorprende extraordinariamente constatar hasta qué punto es Platón consciente de que las «transgresiones morales» más sutiles y, por tanto, peligrosas, en el arte, no se dan de modo explícito (en el contenido del mensaje), sino implícito (a través de su «descontextualización» formal).

De ahí la necesidad de que la élite del Estado se ejercite en dicha práctica: estando ya por encima de los poetas mismos, por sus cualidades y educación, en lo que concierne a la rectitud y utilidad de la poesía (asuntos que no son de la incumbencia del poeta, 670e), su formación en todo lo relativo a la armonía y al ritmo les permitirá competir con ellos ventajosamente (y finalmente suplantarlos), en «inspirar a los jóvenes con su canto el encanto de la virtud» (671a). Esta es, en mi opinión, la novedad más significativa de las Leyes en relación con la poesía: la transferencia de su poder de hechizo y persuasión al legislador, que se consumará en el libro VII.

Los comentarios dedicados a la poesía en el libro III (770a-701c) abundan en la necesidad de implantar la más pura ortodoxia estilística y rítmica, pero algunos re- 
sultan extraordinariamente importantes, en primer lugar, porque recuperan la vieja concepción del poeta como un ser theîon kaì entheastikón (682a); en segundo lugar, porque es a ese tipo de poetas, admirados por Platón antaño, a quienes responsabiliza del proceso de corrupción —en un primer momento poética, más tarde, por «contaminación», política - que ha conducido a los desmanes contemporáneos de toda clase: algunos de esos poetas genuinos

... aunque naturalmente dotados para la poesía, se convirtieron en los iniciadores de la ilegalidad antimusical, ignorantes de la justicia y normas de la Musa; en éxtasis y dominados por el placer más de lo debido, mezclaron trenos con himnos, peanes con ditirambos..., uniendo todo con todo. Llegaron inconscientemente por su misma insensatez a calumniar a la música, diciendo que en esta no cabía rectitud de ninguna clase, y que el mejor juicio estaba en el placer del que se gozaba con ella, fuera este mejor o peor. Haciendo esta clase de composiciones..., inspiraron a la multitud la transgresión de las leyes relativas a la música y la osadía de creerse capaces de juzgar. (...) Y si hubiera sido sólo en la música donde se hubiese producido una cierta democracia de hombres libres, no hubiera sido el hecho tan terrible; pero lo cierto es que a partir de ella empezó para nosotros la opinión de que todo el mundo lo sabía todo y estaba sobre la ley... (700a-701b).

Parecida trascendencia podemos atribuir el comentario, también aislado, del libro IV, donde Platón narra un «viejo» mito, puesto en boca de un poeta imaginario, que nos trae a la memoria sus antiguas tesis sobre la poesía:

Es un mito ya antiguo, oh legislador, siempre referido por nosotros y por todos aceptado, que el poeta, cuando se sienta sobre el trípode la Musa, no está en sus cabales, y que, como una fuente deja brotar todo aquello que le viene a las mientes; además, como su arte es una especie de representación, se ve obligado, al representar hombres de caracteres contrarios, a decir cosas en las que se contradice a sí mismo y no sabe si algo de lo que ha dicho responde a la verdad (719c).

El mito sostiene que el poeta crea poseído por la Musa, y que su creación no responde a la ley de la razón, ni está sujeta a normas; por eso representa contradictoriamente lo que es objeto de su mímesis, algo tan importante como la conducta humana: porque no atiende a la verdad, que es siempre una y unívoca. Por eso también puede «decir algo contrario a las leyes y con ello hacer daño a la ciudad» (719b). No hay labor más opuesta a la del poeta que la del legislador, que debe confirmar realidades y ordenar comportamientos, partiendo siempre de ese principio que impide sostener ideas opuestas sobre una misma cosa $(719 d)^{23}$. El poeta «está siempre a la izquierda del sentir oficial. En la economía, siempre bajo presión, de medios y obligaciones cívicos, lo estético puede conllevar derroche y subversión a la vez ${ }^{24}$.

Finalmente, en el libro VII (798d), y a partir de una exigencia sumaria (Dedóchtho mèn dé tò átopon toûto, nómous tàs oidàs hemîn gegonénai, 799e), regula Platón las

\footnotetext{
${ }^{23}$ Lledó (2010: p. 115).

${ }^{24}$ Steiner (2012: p.60).
} 
medidas para «sanear» las nuevas creaciones poéticas (800e-801c), que no se ofrecerán al público sin la aprobación del legislador (801d (801d); pero también las antiguas, de las que se conservarán únicamente las que respondan a dichas medidas, o, en su defecto, sean susceptibles de hacerlo mediante «correcciones» (802a-b), de las cuales se encargarán los poetas, pero «sin dejarles libertad en cuanto a sus gustos y aficiones» (802c).

Una última cuestión queda por abordar respecto a la poesía: su aprendizaje memorístico en la escuela, supuestamente imprescindible para «todo el que quiera entre nosotros ser persona decente y sabia en experiencias y conocimientos» (agathòs kaì sophòs ek polypeirías kai polymathías, 811a). El Ateniense sostiene, sin embargo, que «una gran erudición representa un peligro para los niños» (811b), y propone como modelo de aprendizaje alternativo el tipo de discurso argumentado y dialógico usado por ellos mismos, «no sin cierta inspiración divina», y «enunciado en una forma sumamente parecida a la de una poesía» (811c).

Si la poesía se convierte en ley; si es sustituida en la escuela por el diálogo filosófico como modelo de aprendizaje; si, además, el filósofo-legislador se apropia de sus divinas fuentes y habla como el poeta, no queda más que concluir que, definitivamente, lo suplanta: y así lo manifiesta Platón en «su» respuesta a la pregunta que seguramente plantearían los poetas trágicos de otros estados sobre la posibilidad de representar en este sus obras:

Nosotros somos también, en la medida de lo posible, poetas, poetas trágicos de la más hermosa y mejor de las tragedias. Toda nuestra constitución política consiste en una representación de la vida mejor y más noble. A esto llamamos nosotros realmente la más verdadera tragedia. Vosotros sois poetas, es cierto, pero nosotros también lo somos en el mismo sentido (817b).

Platón había sentado ya las bases teóricas de esta conclusión en el Sofista, 265b$268 \mathrm{~d}$, y especialmente en 267 a y ss., donde perfila un tipo de creación imitativa, realizada por medio de la persona misma, que resulta de un género superior cuando el imitador conoce lo que imita (eidós), y lo imitado no es un objeto, sino la justicia o la virtud: en este caso, la mímesis es recreación de una realidad ${ }^{25}$, pero sólo está al alcance de los verdaderamente justos y virtuosos. La verdadera poesía es, por tanto, constituir y realizar un Estado perfecto que posibilite a cada uno de sus ciudadanos parecerse a los dioses «todo cuanto le está permitido a un hombre»: mímesis mundana del Bien transmundano, que no necesita ya de los dueños de «una poesía y una Musa bien logradas», sino de hombres buenos, aunque poco dotados artísticamente (829c-d).

La polis de Platón, como en su momento aseguró Pericles de Atenas, «ya no necesita a Homero ni a Demócrito. Los seres humanos hallan su realización a través del arte supremo que es sin duda el de la política»; el cual proporciona «una sensibilidad razonada tanto hacia los ideales como hacia los aspectos prácticos del orden social,

${ }^{25}$ Lledó (2010: pp.79-84). 
de la maduración institucional, más ricos, más adultos (el criterio de Freud) que las fingidas representaciones miméticas. $\gg{ }^{26}$.

IV. Podríamos decir, a modo de conclusión, que toda la reflexión platónica sobre la poesía gira en torno a un problema que ya se plantea como tal en Hesíodo: el de la pérdida de autoconciencia por parte del receptor y su vulnerabilidad al «engaño». Esta percepción va inexorablemente unida a la conciencia por parte del poeta de la intervención humana en el proceso creativo. Tanto Hesíodo como, siglos después, Píndaro, establecen como premisa la antítesis entre buena y mala poesía, entendiendo por buena la que procura al oyente un «abandono» parcial y éticamente productivo: Hesíodo ofrece a su público recordar su original y divina condición perdida, y evocar una visión intrínsecamente superior a la mundana; Píndaro le inspira la autoconciencia de su propia areté, y un éros piadoso que le permite liberarse del phthónos y vivir en armonioso entendimiento colectivo.

Este precario equilibrio se quiebra a mediados del siglo v, en el que poetas como Aristófanes y Eurípides dan fe de la dificultad para sostener, en las condiciones intelectuales y políticas contemporáneas, el antiguo vínculo entre la trascendencia que garantiza el «hechizo» poético, el abandono del receptor, y la necesidad de ofrecerle modelos de conducta útiles para la vida práctica. Ambos intentan denodadamente restablecer esa vieja unidad, de cuya imposibilidad parece en buena medida responsable la nueva concepción del lenguaje como téchne, que arranca en Gorgias.

Platón, por su parte, oscila entre la aceptación del modelo poético «entusiástico», que arrastra al receptor al dominio de lo divino - aceptación plena en el Fedro, problemática en el Ion, donde se resuelve despojando a la poesía de su uso pedagógico-; el rechazo (también pleno) de la República (cuyo ideal político-pedagógico dialéctico excluye la posibilidad de asumir el «hechizo» de la mímesis poética); y la peculiarísima síntesis de las Leyes en la figura del legislador-poeta como artífice de la verdadera poesía, la única capaz de satisfacer necesidades antagónicas, uniendo lo trascendente y lo práctico, lo divino y lo humano.

Resulta obvio que Platón estuvo siempre del lado de la poesía tradicional, llena de los dioses, pero no pudo eludir, como le ocurrió a la generación precedente, la necesidad de adaptarla (de forma más o menos drástica) a los imperativos éticos e intelectuales de los nuevos tiempos. Esta necesidad, en su caso, llegó a ser acuciante cuando se impuso su vocación política como la vía más apta y moral, frente a la poética, para materializar su peculiar concepción del éros, que debe tanto (o en la que tanto coincide, al menos), a la de poetas como Píndaro y Eurípides, como Empédocles también (un poeta-pensador político sin conflictos, el más claro precedente del genio platónico ${ }^{27}$. Hasta este momento, la poesía era el «enemigo», simplemente por su inadecuado uso pedagógico; pero, por esa misma razón, Platón puede aún permitirse - tras desvalorizar los nuevos modelos «técnicos» de creación y crítica poéticas que, para colmo, reivindican el viejo didactismo - mostrar su entusiasmo por la poesía que emana de la divina posesión, la cual es a la vez su fuerza y su debilidad. ¿Qué hacer con ella, sin

\footnotetext{
${ }^{26}$ Steiner (2012: pp. 64-65).

${ }^{27}$ Colli (2011: pp. 101-128), y Steiner (2012: pp. 45s.).
} 
embargo, a la hora de idear un Estado? Este es el dilema que se le plantea a Platón en la República y las Leyes. En la primera, el sometimiento de la poesía a las necesidades del Estado pasa por prohibirla casi en su totalidad, permitiendo únicamente los géneros cuyo mensaje y efectos en el receptor resultan accesibles al control del filósofo. Lógicamente, jamás se acepta en este diálogo la naturaleza divina de la creación poética (¿cómo justificar su censura, o, lo que es más complejo, cómo someter y regular su práctica?). Platón asume que los grandes logros exigen grandes sacrificios. Pero, por otra parte, su renuncia a la poesía implica, en mi opinión, un profundo respeto por su idiosincrasia, y una dolorosa coherencia. Al concluir el análisis de este diálogo, hemos hablado de una falsa síntesis «forzada». Pero, en rigor, la verdadera síntesis (si así puede llamarse) no se consuma hasta las Leyes, donde las necesidades reales se imponen sobre el ideal, las leyes y la religión sobre la educación en la dialéctica, y la suplantación del poeta por el legislador sobre su control externo.

Steiner (2012: pp. 62 y 65) destaca de Platón, en general, su lucha por «mantener a raya al supremo dramaturgo, al fabricante de mitos y narrador de genio que hay dentro de sus propias facultades»; y de las Leyes, en particular, el enorme esfuerzo por «incorporar... al gran estilista y dramaturgo que tiene dentro».

Y todo ello, es, sin duda, incuestionable. Pero, en nuestro caso, no podemos dejar de destacar el altísimo coste que tuvo para Platón la conclusión de este proceso, y cuán irreparable fue la pérdida: en efecto, basta constatar que el tipo de poesía que definitivamente se implanta en las Leyes es cultual y religiosa, pero ha cortado, en el fondo, sus más profundos vínculos con lo divino, en favor de unos modelos de excelencia pragmáticos y racionales, al alcance del receptor y manejables para el legislador, que, pese a todo, cierran la vía de acceso a esas otras aspiraciones y experiencias inefables a las que tanto debe el propio pensamiento platónico. Una poesía que no es ya inspirada, y tampoco «técnica»: definitivamente mutilada en la irrenunciable dualidad de sus aspiraciones. Y todo ese esfuerzo titánico para llegar, como sostiene Nietzsche (1988: pp. 120s.), «a través de un rodeo, justo al lugar en que, como poeta, había tenido siempre su hogar...».

\section{BIBLIOGRAFÍA}

CAssirer, Ernts (1971), Filosofía de las formas simbólicas. I. El lenguaje, México.

Collard, C., Cropp, M.J. y Gibert, J. (2004), Euripides. Selected Fragmentary Plays. Volume II, Oxford.

Colli, Giorgio (2011), Filósofos sobrehumanos, Madrid.

Colli, Giorgio (2008), Platón político, Madrid.

García Gual, Carlos, Martínez Hernández, M. y Lledó, Emilio (1986), Platón. Diálogos III. Fedón, Banquete, Fedro, Madrid.

Gentili, Bruno (1996), Poesía y público en la Grecia Antigua, Barcelona.

Lledó, Emilio (2010), El concepto de poíesis en la filosofía griega. Heráclito, sofistas, Platón, Madrid. 
MAs, Salvador (1992), «Platón y Aristóteles: sobre filosofía y poesía», Estudios y textos. Platón y Aristóteles, Suplementos Anthropos, 32, pp. 5-10.

Most, G. W. (2011), «What Ancient Quarrel between Phisosophy and Poetry», en Destrée \& Herrmann (eds.), Plato and the Poets, Leiden-Boston, pp. 3-12.

Murdoch, Irish (1982), El fuego y el sol. Por qué Platón desterró a los artistas, México.

NiETzSChe, Friedrich (1988): El nacimiento de la tragedia. O Grecia y el pesimismo, Madrid..

Nussbaum, Martha C. (1995), La fragilidad del bien. Fortuna y ética en la tragedia y la filosofia griegas, Madrid.

Pabón, José M. a y Fernández Galiano, Manuel (1969), Platón. La República, Madrid.

Pabón, José M. a y Fernández Galiano, Manuel (1960), Platón. Las Leyes, Madrid.

Ronchi, Rocco (1996), La verdad en el espejo. Los presocráticos y el alba de la filosofía, Madrid.

StEINER, George (2011), La poesía del pensamiento. Del helenismo a Celan, Madrid.

Walsh, George B. (1984), The Varieties of Enchantment. Early Greek Views of the Nature and Function of Poetry, Chapel Hill and London. 